\title{
Burung yang Baik Dipelihara dan Tidak \\ dalam Serat Ngalamating Kutut
}

\author{
Mirya Anggraini \\ Fakultas Ilmu Budaya, Universitas Diponegoro \\ mememirya@gmail.com
}

\begin{abstract}
This study aims to reveal the meaning of the pekutut bird in Serat Ngalamating Kutut. Material object of this research is Serat Ngalamating Kutut. Serat Ngalamating Kutut consists of nineteen stanzas and contains myths about perkutut bird. The text describes fifteen kinds perkutut bird. Of the fifteen kinds can be divided into two. Nine kinds are good turtles and the other six are bad birds. The results showed, the characteristics of perkutut birds that have good and bad influence there is in the text. Birds that have good characteristic are recommended to maintain. Contrarily, birds that have bird characteristics that can bring problems are not recommended, even forbidden to maintain.
\end{abstract}

Keywords: bird, good, bad, myth, keep.

\section{Intisari}

Penelitian ini bertujuan mengungkapkan makna burung perkutut dalam Serat Ngalamating Kutut. Objek material penetian ini adalah Serat Ngalamating Kutut. Serat Ngalamating Kutut terdiri atas sembilan belas bait dan berisi mitos tentang burung perkutut.Teks tersebut menguraikan lima belas macam burung perkutut. Dari kelima belas macam tersebut dapat dibagi menjadi dua. Sembilan macam adalah burung perkutut yang baik dan enam macam yang lain merupakan burung yang buruk. Hasil penelitian menunjukkan, ciri-ciri burung perkutut yang memiliki pengaruh baik dan tidak baik itu terdapat dalam teks. Burung yang memiliki ciri-ciri yang baik dianjurkan untuk dipelihara. Sebaliknya, burung yang memiliki ciri-ciri burung yang dapat mendatangkan masalah tidak dianjurkan, bahkan dilarang keras untuk dipelihara.

Kata kunci: burung, baik, buruk, mitos, pelihara.

\section{Pendahuluan}

Dalam naskah nusantara sering terkandung sesuatu yang berharga. Dengan mempelajarinya dapat diketahui pikiran dan cita-cita para nenek moyang bangsa Indonesia (Robson, 1978:5). Kandungan yang tersimpan dalam karya-karya sastra masa lampau tersebut pada hakikatnya merupakan produk suatu budaya (Baried dkk, 1994:2).

Salah satu produk budaya Jawa adalah memelihara burung perkutut. Burung tersebut merupakan salah satu simbol gengsi bagi priayi Jawa. Selain burung, simbol gengsi yang lain adalah pusaka dan wanita (Purwadi, 2007:394). Burung perkutut sebagai salah satu simbol 
gengsi priayi Jawa ternyata tercatat dalam sumber tertulis. Salah satu teks yang membicarakan tentang burung perkutut adalah Serat Ngalamating Kutut.

Serat Ngalamating Kutut terdiri atas 19 bait yang berisi mitos tentang burung perkutut. Teks itu terdapat di Keraton Yogyakarta(Lindsay, 1994:204). Dengan demikian mitos tentang burung perkutut juga menyebar di kalangan istana.

Dalam budaya Jawa, burungperkutut adalah binatang sakral dan penuh mitos. Hal itu karena pengaruh dari legenda Joko Mangu. Legenda tersebut bercerita tentang burung perkutut milik Prabu Brawijaya V yang merupakan jelmaan Pangeran Pajajaran, bernama Joko Mangu. Suatu hari burung perkutut itu lepas dari sangkar, tetapi berhasil ditemukan oleh sang raja dalam perjalanannya ke wilayah Yogyakarta. Sejak saat itu hingga sekarang, rajaraja Mataram keturunan Prabu Brawijaya selalu melestarikan tradisimemelihara burung perkutut.

Tradisi memelihara burung perkutut itu kemudian dicontoh oleh masyarakat Jawa karena dianggap memiliki nilai-nilai budaya adiluhung. Lebih dari itu, masyarakat Jawa percaya bahwa burung perkutut memiliki kekuatan yang dapat mempengaruhi pemiliknya sehingga muncul mitos-mitos yang berkaitan dengan burung perkutut. Banyak burung perkutut yang berdasarkan ciri-cirinya dipercaya oleh masyarakat Jawa memiliki pengaruh baik (keberuntungan) dan tidak baik bagi orang yang memeliharanya.

\section{Perkutut dalam Serat Ngalamating Kutut}

Ciri-ciri burung perkutut yang memiliki pengaruh baik dan tidak baik itu tertuang dalam Serat Ngalamating Kutut ini. Burung yang memiliki ciri-ciri yang baik dianjurkan untuk dipelihara. Sebaliknya, burung yang memiliki ciri-ciri burung yang dapat mendatangkan mala dianjurkan, bahkan dilarang keras untuk memeliharanya.

\section{Perkutut yang baik dipelihara}

Burung perkutut yang memiliki pengaruh baik adalah burung yang membawa keberuntungan bagi yang memelihara. Adapun burung perkutut yang baik dipelihara itu ialah.

\section{Sri Pangepel}

Salah satu burung perkutut yang baik dipelihara disebut Sri Pangepel. Berikut bait yang memuat hal tersebut.

angingua kutut ingkang putih / Peliharalah perkutut yang putih driji putih tinom /
Jarinya terlihat putih keabuan 
lan kuku jempol putih karone / sri pangepel arane kang paksi / ngon ingoning tani / sri sadana lutut //
Juga kedua jempolnya

Sri Pangepel itu nama burungnya

Peliharaannya petani

Kemuliaan kekayaan

(Serat Ngalamating Kutut bait 2)

Dalam bait di atas disebutkan bahwa Sri Pangepel merupakan jenis burung perkutut yang berbulu putih. Burung ini juga memiliki ciri jari dan jempolnya berwarna putih keabuan.

Burung ini baik untuk dipelihara oleh petani karena akan membawa kemuliaan dan kemakmuran bagi yang memeliharanya.

\section{Wisnu Citra}

Burung selanjutnya yang baik untuk dipelihara adalah Wisnu Citra. Berikut bait yang menyebutkan hal itu.

$\begin{array}{ll}\text { padha sira angingua paksi / } & \text { Kamu peliharalah burung } \\ \text { ingkang ireng tinon / } & \text { Yang hitam keabu-abuan } \\ \text { tekeng cucuk utawa sikile / } & \text { Sampai paruh ataupun kakinya } \\ \text { lawan sisik semu ireng nenggih / } & \text { Tanpa sisik kehitaman yaitu } \\ \text { wisnu citra nami / } & \text { Yang bernama wisnu citra } \\ \text { becike kalangkung // } & \text { Lebih baik }\end{array}$

(Serat Ngalamating Kutut bait 4)

Wisnu Citra merupakan jenis burung perkutut yang memiliki bulu, paruh, dan kaki berwarna hitam keabu-abuan. Namun, bulunya itu tidak memiliki sisik berwarna kehitaman. Burung yang berciri demikian merupakan burung yang sangat baik untuk dipelihara karena akan membawa hal baik bagi yang memelihara.

\section{Wisnu Mangenu}

Selain Wisnu Citra, ada burung yang disebut Wisnu Mangenu yang juga baik untuk dipelihara. Berikut bait yang menyebutkan hal itu.

$\begin{array}{ll}\text { lah ta sira angingua paksi / } & \text { Sebaiknya kamu memelihara burung } \\ \text { semu ireng tinon / } & \text { Yang warnanya Hitam keabu-abuan } \\ \text { sak srandune awak ira kabeh / } & \text { Di seluruh tubuhnya } \\ \text { wisnu mangenu arane paksi / } & \text { Burung itu disebut burung WisnuMangenu } \\ \text { serepan rejeki / } & \text { Akan membawa keberuntungan } \\ \text { epeh peksi iku // } & \text { Karena bawaan dari burung itu }\end{array}$

(Serat Ngalamating Kutut bait 6)

Wisnu Mangenu merupakan jenis burung perkutut yang bulu dan seluruh tubuhnya berwarna hitam keabu-abuan. Burung ini merupakan burung yang istimewa karena akan membawa keberuntungan bagi yang memelihara. 


\section{Kusumawicitra}

Burung lain yang baik untuk dipelihara disebut Kusumawicitra. Hal itu terdapat dalam bait berikut.

$\begin{array}{ll}\text { angingua paksi semu putih/ } & \text { Peliharalah burung yang berwarna keputihan } \\ \text { cucuk sikil mangke / } & \text { Paruh dan kakinya panjang } \\ \text { pan abecik punika lamate / } & \text { Hal itu merupakan pertanda baik } \\ \text { aran kusumawicitra nenggih / } & \text { Disebut juga kusumawicitra } \\ \text { barang karya dadi / } & \text { Hasil yang sudah jadi } \\ \text { rejeki dinulur // } & \text { Rejeki yang ditanam }\end{array}$

(Serat Ngalamating Kutut bait 7)

Kusumawicitra merupakan jenis burung perkutut yang bulunya berwarna semu putih. Burung ini memiliki paruh dan kaki yang panjang. Siapa saja yang memelihara burung ini akan mendapatkan rejeki yang terus menerus.

\section{Pandhitamijil}

Pandhitamijil merupakan jenis burung perkutut yang baik dipelihara. Berikut bait yang memuat hal itu.

$\begin{array}{ll}\text { lamun sira arsa ngingu paksi / } & \text { Jika kamu ingin memelihara burung } \\ \text { butute kang tinon / } & \text { Lihatlah ekornya } \\ \text { den wilanga yen limalas kehe / } & \text { yang jumlahnya lima belas } \\ \text { den arani sang Padhitamijil/ } & \text { Yang dinamakan Pandhitamijil } \\ \text { lamate abecik / } & \text { Pertanda baik } \\ \text { keringan kang ngingu // } & \text { keinginan besar bagi yang memelihara } \\ & \text { (Serat Ngalamating Kutut bait 8) }\end{array}$

Menurut bait di atas, burung ini memiliki bulu ekor berjumlah lima belas. Pemeliharanya akan dihormati oleh orang lain.

\section{Purnamasidi}

Burung lain yang baik untuk dipelihara adalah perkutut yang disebut Purnamasidi. Berikut bait yang memuat hal itu.
lah ta sira ngingua paksi /
Dan kamu peliharalah burung
netra bang sumarot $/$
Dengan mata yang memancarkan kemerahan
anglir mirah sela ing netrane /
Seperti merah disela matanya
wastaning paksi Purnamasidi /
Namanya burung Purnamasidi
jalma kathah asih /
Manusia banyak yang suka
awingit kang ngingu //
Menyenangkan yang memelihara
(Serat Ngalamating Kutut bait 9) 
Purnamasidi merupakan jenis burung perkutut yang memiliki warna merah di sela-sela matanya sehingga mata burung itu seolah memancarkan sinar kemerahan. Burung semacam itu baik untuk dipelihara karena yang memelihara akan disenangi dan disegani oleh orang lain.

\section{Sinusuh Siti}

Selanjutnya, ada burung yang disebut Sinusuh Siti. Burung tersebut juga baik untuk dipelihara. Berikut bait yang memuat hal itu.

$\begin{array}{ll}\text { lah nginguwa pan sinusuh siti / } & \text { Peliharalah sinusuh siti } \\ \text { becik keraraton / } & \text { Baik kelihatannya } \\ \text { tejanira den abonga mangke / } & \text { Cahayanya akan terbakar nanti } \\ \text { awonira kinarya jejampi / } & \text { Kejelekannya digunakan untuk obat } \\ \text { waras barang sakit / } & \text { Menyembuhkan yang sakit } \\ \text { yen kinarya adus // } & \text { Jika digunakan untuk mandi }\end{array}$

(Serat Ngalamating Kutut bait 10)

Sinusuh Siti merupakan jenis burung perkutut yang dipercaya akan mendatangkan kesehatan bagi yang memeliharanya. Burung ini bersarang di tanah dan dapat dijadikan obat.

\section{Marcujiwa}

Burung lain yang baik untuk dipelihara dinamakan Marcujiwa. Berikut bait yang memuat hal itu.

$\begin{array}{ll}\text { lah nginguwa paksi netra kuning / } & \text { Peliharalah burung bermata kuning } \\ \text { kang jait sumarot / } & \text { Yang terpancar iris matanya } \\ \text { marcujiwa punika wastane / } & \text { Marcujiwa disebutnya } \\ \text { lamatipun nelaken rejeki / } & \text { Tandanya melancarkan rejeki } \\ \text { den lututi jalmi / } & \text { Yang diinginkan manusia } \\ \text { sarayate ayu // } & \text { Yang terlihat tercantik }\end{array}$

(Serat Ngalamating Kutut bait 11)

Marcujiwa merupakan jenis burung perkutut yang iris matanya bermata kuning sehingga memancarkan sinar kekuningan. Burung semacam ini dipercaya dapat melancarkan rejeki bagi yang memelihara.

\section{Mustikaning Paksi}

Burung yang sangat baik untuk dipelihara adalah Mustikaning Paksi. Berikut bait yang memuat hal tersebut.

lamun ana paksi netra putih / berus awak tinon /
Kalau ada burung bermata putih

Paruh berwarna abu-abu 
sak srandune semu pethak mangke / Seluruh badan keputihan

iya iku mustikaning paksi /

Itulah permatanya burung

tan ngenger wong cilik /

tidak dipelihara orang kecil

ngon ingoning ratu //

Peliharaan Sang Ratu

(Serat Ngalamating Kutut bait 12)

Mustikaning paksi merupakan jenis burung perkutut yang bulu dan matanya berwarna putih sedangkan paruhnya berwarna abu-abu. Burung semacam ini dipercaya sebagai burung peliharaan raja sehingga siapa saja yang memeliharanya akan mendapat keutamaan seperti seorang raja.

\section{Marcujia}

Burung yang juga baik untuk dipelihara disebut Marcujia. Berikut bait yang memuat hal itu.

$\begin{array}{ll}\text { lamun ana peksi netra kuning / } & \text { Jika ada burung bermata kuning } \\ \text { berus ing breratol / } & \text { Dengan paruh yang tajam } \\ \text { marcujia punika arane / } & \text { Marcujia itu namanya } \\ \text { sakathahe becik dadi siji / } & \text { Semua kebaikan menjadi satu } \\ \text { tan dingu wong cilik/ } & \text { Tidak dipelihara orang kecil } \\ \text { ngon ingoning ratu // } & \text { Tapi dipelihara ratu }\end{array}$

(Serat Ngalamating Kutut bait 13)

Marcujia merupakan burung perkutut yang matanya berwarna kuning dan paruhnya tajam. Burung ini merupakan lambang kebaikan dan dipercaya sebagai burung peliharaan raja. Jika memelihara burung itu, akan mendapat seluruh kebaikan di dunia.

\section{Inep Gedhong}

Selanjutnya, ada burung yang disebut Inep Gedhong. Burung tersebut juga baik untuk dipelihara. Berikut bait yang memuat hal itu.

lamun ana paksi sore muni / Jika ada burung berkicau di sore hari

aran inep gedhong / Disebut Inep gedhong

lamatipun ngulihken donyane / Tandanya akan pulang ke alamnya

lan nekaken pangan ingkang suci / Dan membawa makanan yang berkah

sugih beras pari /

Kaya beras dan padi

basuki kang ngingu //

Selamat yang memeliharanya

(Serat Ngalamating Kutut bait 15)

Inep gedhong merupakan jenis burung perkutut yang kicauannya dan manggungnya di sore hari. Burung seperti itu dipercaya akan membawa berkah, rejeki, dan keselamatan bagi yang memeliharanya. 


\section{Gedhong Mengo}

Burung lain yang baik dipelihara disebut Gedhong Mengo. Berikut bait yang memuat hal itu.

lamun peksi munya pendhak enjing / Jika burung yang berkicau di pagi hari sareng surya katon / Seiring terbitnya matahari pan abecik punika lamate / Itu pertanda baik gedhong menga kedah den leboni / Gedhong mengo harus dimasuki emas lawan picis / Emas dan uang kang ngingu rahayu // Untuk memelihara keselamatan (Serat Ngalamating Kutut bait 17)

Gedhong mengo merupakan jenis burung perkutut yang berkicau di pagi hari seiring dengan terbitnya matahari. Kicauan burung ini merupakan pertanda baik sehingga siapa saja yang memelihara burung ini dipercaya akan mendapatkan rejeki dan keselamatan.

Uraian di atas merupakan burung perkutut yang baik dipelihara. Di samping itu, ada juga burung perkutut yang sebaiknya tidak dipelihara.

\section{Perkutut yang buruk dipelihara}

Adapun burung perkutut yang memiliki pengaruh tidak baik adalah burung yang membawa kesusahan dan ketidakberuntungan bagi yang memelihara. Adapun burung perkutut yang tidak baik dipelihara itu ialah.

\section{Bramasulur}

Bramasulur merupakan jenis burung perkutut tidak baik dipelihara Berikut bait yang memuat hal itu.

$\begin{array}{ll}\text { lamun sira arsa ngingu paksi / } & \text { Jika kamu ingin memelihara burung } \\ \text { brakutut wong anom / } & \text { Perkutut,anak muda } \\ \text { aja ngingu kang abang buntute / } & \text { Jangan memelihara yang merah ekornya } \\ \text { Bramasulur arane kang paksi / } & \text { Bramasulur nama burungnya } \\ \text { lamat nora becik / } & \text { Itu pertanda tidak baik } \\ \text { greringan kang ngingu // } & \text { Menjadi kurus yang memeliharanya }\end{array}$

(Serat Ngalamating Kutut bait 1)

Seperti disebutkan pada bait di atas, Bramasulur adalah jenis burung perkutut yang berekor merah. Jenis perkutut ini tidak boleh dipelihara karena yang memelihara akan sakit-sakitan dan menjadi kurus. 


\section{Brama Lebu}

Burung lain yang tidak baik dipelihara adalah perkutut yang dinamakan Brama Lebu. Tanda tentang burung ini ada pada bait ketiga berikut.

$\begin{array}{ll}\text { aja ngingu paksi napas nenggih / } & \text { Jangan memelihara burung abu-abu kekuningan } \\ \text { lamatipun awon / } & \text { pertanda tidak baik } \\ \text { brama lebu punika arane / } & \text { Disebut Brama Lebu } \\ \text { panas barang watake kang jalmi / } & \text { Membawa celaka bagi manusia } \\ \text { tutuke ngarang arengit / } & \text { Mulutnya hitam } \\ \text { lan adhemen padu // } & \text { Dan sukanya bertengkar }\end{array}$
(Serat Ngalamating Kutut bait 3)

Brama lebu merupakan jenis burung perkutut yang bulunya berwarna abu-abu kekuningkuningan. Burung ini kurang enak dipandang dan memiliki paruh berwarna hitam. Burung jenis ini dilarang dipelihara karena akan membawa celaka bagi yang memeliharanya.

\section{Brama Kala}

Burung lain yang sebaiknya tidak dipelihara disebut Brama Kala. Mitos tentang burung ini tertulis pada bait kelima berikut.

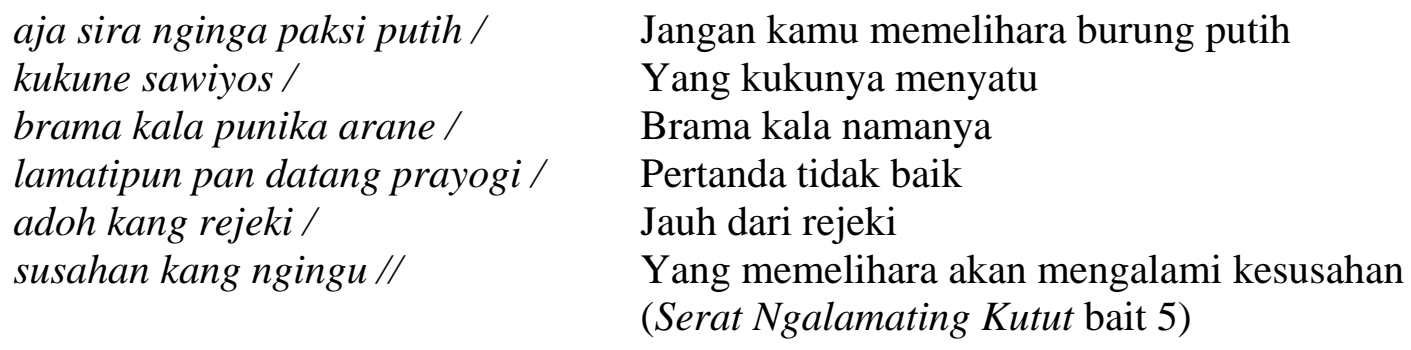

Brama kala merupakan jenis burung perkutut yang bulunya berwarna putih dan kukunya menyatu. Burung jenis ini tidak baik dipelihara karena akan membawa nasib buruk bagi yang memelihara. Pemelihara burung ini akan jauh dari rejeki dan mengalami kesusahan.

\section{Bramakakop}

Selanjutnya, burung yang harus dihindari untuk dipelihara adalah perkutut yang disebut Bramakakop. Mitos burung itu ada dalam bait ke-14 berikut.




Bramakakop arane kang paksi / arsa wruh ing getih / getihe kang ngingu //
Bramakakop namanya

Ingin melihat darah

Darah yang memelihara

(Serat Ngalamating Kutut bait 14)

Bramakakop merupakan jenis burung perkutut yang bulu, muka, dan paruhnya berwarna putih. Burung ini tidak baik jika dipelihara karena burung ini suka melihat darah yang memeliharanya. Sehingga, siapa pun yang memelihara burung ini akan mendapatkan celaka bahkan kematian.

\section{Durna Ngerik}

Burung lain yang tidak boleh dipelihara adalah perkutut yang disebut Durna Ngerik. Berikut bait yang memuat hal tersebut.
lamun paksi esuk sore muni /
Jika burung berbunyi pagi dan sore lamatipun awon / Pertanda buruk durna ngerik pan ika arane / Durna Ngerik itu namanya mangggung tukar myang anak rabi / Berbunyi bersahut-sahutan pada anak-anaknya adoh kang rijiki / Akan jauh dari rejeki eluh kerep metu // Air mata sering keluar (Serat Ngalamating Kutut bait 16)

Durna Ngerik merupakan jenis burung perkutut yang selalu berkicau di pagi dan sore hari. Kicauan burung ini bersahut-sahutan satu dengan yang lainnya. Dalam pupuh ini disebutkan bahwa siapa saja yang memelihara burung perkutut jenis ini akan memiliki nasib buruk. Pemiliknya akan jauh dari rejeki dan mengalami kesusahan.

\section{Durga Nguwuh}

Selanjutnya, ada burung perkutut yang disebut Durna Nguwuh. Burung ini juga tidak baik dipelihara.

lamun paksi muni tengah wengi / lamatipun awon / durga nguwuh punika arane / jalu estri geringan aganti / suda kang rijiki / tansah wuyang wuyung //
Jika burung berbunyi di tengah malam

Memberikan tanda yang buruk

Durga nguwuh namanya

Laki-laki dan perempuan bergantian sakit

Berkurang rejekinya

Janganlah merasa khawatir

(Serat Ngalamating Kutut bait 18) 
Durga Nguwuh merupakan jenis burung perkutut yang selalu berkicau di malam hari. Jenis burung ini merupakan salah satu burung yang tidak boleh dipelihara karena akan membawa nasib buruk kepada orang yang memeliharanya. Dalam bait 18 disebutkan bahwa siapa saja yang memelihara burung ini akan mengalami kesusahan dan rejekinya akan berkurang.

Itulah nama-nama dan ciri-ciri burung perkutut yang dianjurkan maupun yang tidak dianjurkan untuk dipelihara.

\section{Kesimpulan}

Serat Ngalamating Kututberisi mitos tentang perkutut, burung yang sering menjadi kelangenan bagi masyarakat Jawa.Teksitu tersebar di masyarakat yang memiliki paham kejawen. Teks tersebut mengandung larangan dan anjuran bagi orang yang mencintai perkutut. Berdasarkan isinya, masyarakat diharapkan percaya tentang sifat-sifat burung perkutut yang baik dan buruk.

Teks tersebut menguraikan lima belas macam burung perkutut. Dari kelima belas macam tersebut dapat dibagi menjadi dua. Sembilan macam adalah burung perkutut yang baik dan sebaiknya dipelihara. Sementara itu, enam macam yang lain merupakan burung yang buruk dan dilarang untuk dipelihara.

\section{Daftar Pustaka}

Baroroh Baried, Siti, dkk. 1994. Pengantar Teori Filologi. Yogyakarta: Badan Penelitian dan Publikasi Fakultas Sastra Universitas Gadjah Mada.

Lindsay, Jennifer dkk. 1994. Katalog Induk Naskah-Naskah Nusantara Jilid 2: Kraton Yogyakarta. Jakarta:Yayasan Obor Indonesia.

Purwadi. 2007. Ensiklopedi Adat Istiadat Budaya Jawa. Yogyakarta: Panji Pustaka.

Robson, S. O. 1978. "Pengkajian Sastra-sastra Tradisional Indonesia" dalam Bahasa dan Sastra Tahun IV Nomor 6. Jakarta: Pusat Pembinaan dan Pengembangan Bahasa Departemen Pendidikan dan Kebudayaan. 